\title{
The effects of stillbirth and abortion on the next pregnancy: a longitudinal study
}

\author{
Berhanu Elfu Feleke ${ }^{1 *} \mathbb{D}$, Teferi Elfu Feleke ${ }^{2}$, Azezu Asres Nigussie ${ }^{3}$ and Eyaya Misgan ${ }^{4}$
}

\begin{abstract}
Background: Abortion and stillbirths are the common obstetrics condition in Ethiopia and their effect on the next pregnancy was not well identified in resource limited settings. The aim of the study was to assess the effect of stillbirth and abortion on the next pregnancy.

Methods: A prospective cohort study design was implemented. The study was conducted in Mecha demographic surveillance and field research center catchment areas. The data were collected from January 2015 to March 2019. Epi-info software was used to calculate the sample size. The systematic random sampling technique was used to select stillbirth and abortion women. Poison regression was used to identify the predictors of MCH service utilization; descriptive statistics were used to identify the prevalence of blood borne pathogens. The Kaplan Meier survival curve was used to estimate survival to pregnancy and pregnancy related medical disorders.
\end{abstract}

Results: 1091 stillbirth and 3,026 abortion women were followed. Hepatitis B was present in 6\% of abortion and 3.2\% of stillbirth women. Hepatitis C was diagnosed in $4.7 \%$ of abortion and $0.3 \%$ of stillbirth women. HIV was detected in $3 \%$ of abortion and $0.8 \%$ of stillbirth women. MCH service utilization was determined by knowledge of contraceptives [IRR 1.29, 95\% Cl 1.18-1.42], tertiary education [IRR 4.29, 95\% Cl 3.72-4.96], secondary education. [IRR 3.14, 95\% Cl 2.73-3.61], married women [IRR 2.08, 95\% Cl 1.84-2.34], family size [IRR $0.67,95 \% \mathrm{Cl} 1.001-1.01]$, the median time of pregnancy after stillbirth and abortion were 12 months. Ante-partum hemorrhage was observed in $23.1 \%$ of pregnant mothers with a past history of abortion cases and post-partum hemorrhage was observed in $25.6 \%$ of pregnant mothers with a past history of abortion. PREGNANCY INDUCED DIABETES MELLITUS was observed $14.3 \%$ of pregnant mothers with a past history of stillbirth and pregnancy-induced hypertension were observed in $9.2 \%$ of mothers with a past history of stillbirth.

Conclusion: Obstetric hemorrhage was the common complications of abortion women while Pregnancy-induced diabetic Mellitus and pregnancy-induced hypertension were the most common complications of stillbirth for the next pregnancy.

Keywords: Fetal death, Pregnancy outcome, Stillbirth, Abortion, Ethiopia

\section{Background}

Delivery of the fetus with no sign of life after 28 weeks of gestation was labeled as stillbirth [1]. According to the world health organization report, more than 2.6 million

\footnotetext{
*Correspondence: elfufeleke@gmail.com

1 Department of Epidemiology and Biostatistics, University of Bahir Dar, Bahir Dar, Ethiopia

Full list of author information is available at the end of the article
}

stillbirths were reported annually [2]. More than $75 \%$ of stillbirths occur in sub-Saharan Africa and South Asia [3]. Placental problems, childbirth complications, infections, congenital anomalies, and intrauterine growth retardation were some of the causes for stillbirth $[4,5]$.

Expulsion of the product of pregnancy before viability, usually 28 weeks of gestational age defines abortion in resource limited settings [6]. Globally more than 25 million unsafe abortions women were reported in 2014, and 
most of them occur in developing countries [7]. Abnormal chromosomes, maternal medical disorders, and unhealthy lifestyles are some of the reasons for abortion women [8]. Uterine perforation, infections, bowel and bladder injury, excessive bleeding are some of the complications of abortion women $[9,10]$.

Abortion was among the top leading causes of maternal mortality. According to the Ethiopian demographic and health surveillance 2016 report, the maternal mortality ratio of Ethiopia was 412 per 100,000 live births [11]. Ethiopia tries to reduce the complications of abortion by expanding the family planning services accessibility and by drafting the legal abortion law [12].

Availing the maternal and child health services significantly decrease maternal mortality. Report suggests that $\mathrm{MCH}$ service utilization was determined by age, birth rank, educational level, monthly income, number of children, occupation, knowledge about sexually transmitted infections, educational status, residence, parity, partner communication, and the presence of TV/radio [13-19].

In resource limited settings, evidence on the effect of stillbirth and abortion women on the next pregnancy was scarce, which affects the quality of maternal and child health services. This research work generates evidence and improves the quality and utilization of maternal and child health services.

The objectives of this study were: to estimate the $\mathrm{MCH}$ service utilization after stillbirth and abortion, to assess the prevalence of blood borne pathogens among stillbirth and abortion women, to estimate the median time of pregnancy after stillbirth and abortion women, to estimate the risk of obstetric hemorrhage and pregnancyinduced medical disorders after stillbirth and abortion women.

\section{Methods}

A Prospective cohort study design was implemented. The study was conducted in the Mecha demographic surveillance and field research center catchment areas, Mecha district. The district was located $30 \mathrm{~km}$ away from Bahir Dar, the capital city of Amhara National Regional State. The data were collected from January 2015 to March 2019. The target population for the study was all mothers with stillbirth or abortion. Women out migrated from the catchment areas were excluded. During update data collection, pregnant mothers with chronic diabetes mellitus or chronic hypertension were excluded. The sample size was calculated using Epi-info software version 7 with the assumption of $95 \% \mathrm{CI}$, power of $90,3: 1$ ratio of abortion women to stillbirth women, a risk ratio of 1.12 and $10 \%$ non-response rate; give 1091 stillbirth and 3171 abortion women. The systematic random sampling technique was used to select both the stillbirths and abortion women.
They were recruited after pregnancy termination. The study participants were selected from the government health facilities of the Mecha district. Interviewing the patient was conducted by midwife professionals and laboratory samples were collected by laboratory technologists. Baseline data were collected from the post-abortion women and stillbirth women in the gynecologic ward using the patient interviews. Then, every three months update data were collected from each study participant from their residence using Mecha demographic surveillance and field research center frame. Clinician-Administered post-traumatic stress disorder Scale (PTSD) was used to screen for post-traumatic stress disorder. Laboratory samples were collected by laboratory technologists. For each study participant, $5 \mathrm{ml}$ (ML) venous blood was collected using an aseptic technique and an Enzyme-linked immune Sorbent assay (ELIZA) test was performed to screen for the presence of hepatitis $\mathrm{B}$ and hepatitis $\mathrm{C}$. The standard operating procedures (SOP) were followed. For pregnant mothers, Peripheral blood was collected to measure blood glucose levels. American diabetic association criteria was used to diagnose gestational diabetic mellitus [20]. Focused ante-natal care (FANC) was given for all pregnant mothers to the nearby health facility.

To increase the quality of data; pretest was performed, the data collection was closely supervised, SOP was adhered to all laboratory procedures, and training was given for all data collectors and supervisors.

Data were entered into the computer using EPI-info software and transferred to SPSS for analysis. Descriptive statistics were used to present the profile of study participants, $\mathrm{MCH}$ service utilization and estimate pregnancy-related complications after stillbirth and abortion women. Poisson regression was used to identify the determinants of $\mathrm{MCH}$ service utilization after stillbirth and abortion women. The Kaplan Meier survival curve was used to estimate time to pregnancy and pregnancyrelated complications.

\section{Results}

A total of 4117 women was included giving for the response rate of $96.6 \%, 64$ women were out-migrated from the study areas and the medical records of 81 women were incomplete. Stillbirth constitutes 1042 study participants. The proportions of stillbirth and abortion women completed the survey was $95.5 \%$ and 96.9\% respectively. The mean age of the study participant was 21.92 years [SD (standard deviation \pm 4.9 years)]. (Table 1).

From 3075 abortion women, $24.09 \%$ of study participants mention rape as a reason for abortion women and $58.08 \%$ of study participants not volunteer to mention 
Table 1 Profile of the study participants $(n=4117)$

\begin{tabular}{|c|c|c|c|c|c|c|c|}
\hline \multirow[t]{2}{*}{$S N^{a}$} & \multirow[t]{2}{*}{ Variables } & & \multicolumn{2}{|l|}{ Stillbirth } & \multicolumn{2}{|l|}{ Abortion } & \multirow[t]{2}{*}{$P$ value } \\
\hline & & & Frequency & $\%$ & Frequency & $\%$ & \\
\hline \multirow[t]{2}{*}{1.} & Knowledge of contraceptive & Present & 955 & 91.7 & 456 & 14.8 & $<0.01$ \\
\hline & & Absent & 87 & 8.3 & 2619 & 85.2 & \\
\hline \multirow[t]{2}{*}{2.} & Resident & Rural & 1020 & 97.9 & 2210 & 71.9 & $<0.01$ \\
\hline & & Urban & 22 & 2.1 & 865 & 28.1 & \\
\hline \multirow[t]{5}{*}{3.} & Educational status & Illiterate & 66 & 6.3 & 603 & 19.6 & $<0.01$ \\
\hline & & Informal & 76 & 7.3 & 1147 & 37.6 & \\
\hline & & Elementary & 2 & 0.2 & 117 & 5.8 & \\
\hline & & Secondary & 36 & 3.5 & 1009 & 32.8 & \\
\hline & & Tertiary & 862 & 82.7 & 139 & 4.5 & \\
\hline \multirow[t]{2}{*}{4.} & TV/radio & Present & 367 & 35.2 & 260 & 8.5 & $<0.01$ \\
\hline & & Absent & 675 & 64.8 & 2815 & 91.5 & \\
\hline \multirow[t]{4}{*}{5.} & Marital status & Single & 46 & 4.4 & 2803 & 91.2 & $<0.01$ \\
\hline & & Married & 981 & 94.1 & 272 & 8.6 & \\
\hline & & Divorced & 11 & 1.1 & 0 & 0 & \\
\hline & & Widowed & 4 & 0.4 & 0 & 0 & \\
\hline \multirow[t]{2}{*}{6.} & Family size & $\leq 4$ & 740 & 71 & 1365 & 44.5 & $<0.01$ \\
\hline & & $>4$ & 302 & 29 & 1710 & 55.6 & \\
\hline \multirow[t]{2}{*}{7.} & Hepatitis C & Positive & 3 & 0.3 & 144 & 4.7 & $<0.01$ \\
\hline & & Negative & 1039 & 99.7 & 2931 & 95.3 & \\
\hline \multirow[t]{2}{*}{8.} & HIV & Positive & 8 & 0.8 & 91 & 3 & $<0.01$ \\
\hline & & Negative & 1034 & 99.2 & 2984 & 97 & \\
\hline \multirow[t]{2}{*}{9.} & Hepatitis B & Positive & 33 & 3.2 & 185 & 6 & $<0.01$ \\
\hline & & Negative & 1009 & 96.8 & 2890 & 94 & \\
\hline \multirow[t]{2}{*}{10.} & Partner communication about $\mathrm{MCH}$ & Present & 350 & 33.6 & 1090 & 35.4 & 0.27 \\
\hline & & Absent & 692 & 66.4 & 1085 & 64.5 & \\
\hline
\end{tabular}

a Serial number

the reason for abortion women. Post traumatic stress syndrome (PTSD) was observed in $44.9 \%$ of study participants (Table 2).

During the consecutive 3 years, maternal and child health service $(\mathrm{MCH})$ was utilized by $42.1 \%$ of study participants. After adjusting for residence, marital status, stillbirth, abortion, family size, age, gravidity, the presence of TV/Radio, knowledge on contraceptive, educational status, access to contraceptives; $\mathrm{MCH}$ service utilization was associated with age, knowledge of contraceptives, educational status, the presence of TV/Radio, marital status, and family size (Table 3 ).
In the subsequent 3 years, $22.8 \%$ of study participants become pregnant and the median time of pregnancy was 12 months (Fig. 1).

Obstetric hemorrhage was the main complication of abortion for the next pregnancy, antepartum hemorrhage (APH) was observed in $23.1 \%$ of pregnant mothers with a past history of abortion and post-partum hemorrhage $(\mathrm{PPH})$ was observed in $25.6 \%$ pregnant mothers with past history of abortion (Fig. 2).

Gestational diabetes mellitus and pregnancy-induced hypertension were the common complications of stillbirth for the next pregnancy; PREGNANCY INDUCED

Table 2 Post traumatic stress disorder in the post abortion and stillbirth women $(n=4117)$

\begin{tabular}{|c|c|c|c|c|c|c|c|c|c|c|}
\hline & \multicolumn{2}{|l|}{ Absent } & \multicolumn{2}{|l|}{ Mild } & \multicolumn{2}{|l|}{ Moderate } & \multicolumn{2}{|l|}{ Severe } & \multicolumn{2}{|l|}{ Extreme } \\
\hline & Frequency & $\%$ & Frequency & $\%$ & Frequency & $\%$ & Frequency & $\%$ & Frequency & $\%$ \\
\hline Stillbirth & 324 & 31.1 & 79 & 7.6 & 420 & 40.3 & 174 & 16.7 & 45 & 4.3 \\
\hline Abortion & 1944 & 63.2 & 1131 & 36.8 & 0 & 0 & 0 & 0 & 0 & 0 \\
\hline
\end{tabular}


Table 3 Poisson regression output for determinants for $\mathrm{MCH}$ services utilization $(n=4117)$

\begin{tabular}{|c|c|c|c|c|c|c|}
\hline \multirow[t]{2}{*}{ Variables } & \multirow[t]{2}{*}{ B } & \multirow[t]{2}{*}{ Standard error } & \multirow[t]{2}{*}{$P$ value } & \multirow[t]{2}{*}{ IRR } & \multicolumn{2}{|c|}{$95 \% \mathrm{Cl}$ for IRR } \\
\hline & & & & & Lower & Upper \\
\hline Knowledge of contraceptives & .257 & .0482 & .000 & 1.293 & 1.176 & 1.421 \\
\hline Access to contraceptives & .088 & .0387 & .023 & 1.092 & 1.012 & 1.178 \\
\hline Tertiary education & 1.458 & .0729 & .000 & 4.296 & 3.724 & 4.955 \\
\hline Secondary education & 1.143 & .0710 & .000 & 3.137 & 2.729 & 3.605 \\
\hline Primary education & -.822 & .2041 & .000 & .440 & .295 & .656 \\
\hline Informal education & -1.097 & .1026 & .000 & .334 & .273 & .408 \\
\hline Presence of TV/Radio & .085 & .0317 & .007 & 1.089 & 1.023 & 1.159 \\
\hline Widowed & .437 & .2606 & .093 & 1.548 & .929 & 2.580 \\
\hline Divorced & .657 & .1599 & .000 & 1.929 & 1.410 & 2.639 \\
\hline Married & .730 & .0612 & .000 & 2.075 & 1.841 & 2.340 \\
\hline High family size & -.405 & .0325 & .000 & .667 & .626 & .711 \\
\hline Age & .005 & .0023 & .027 & 1.005 & 1.001 & 1.010 \\
\hline
\end{tabular}

IRR incident rate ratio

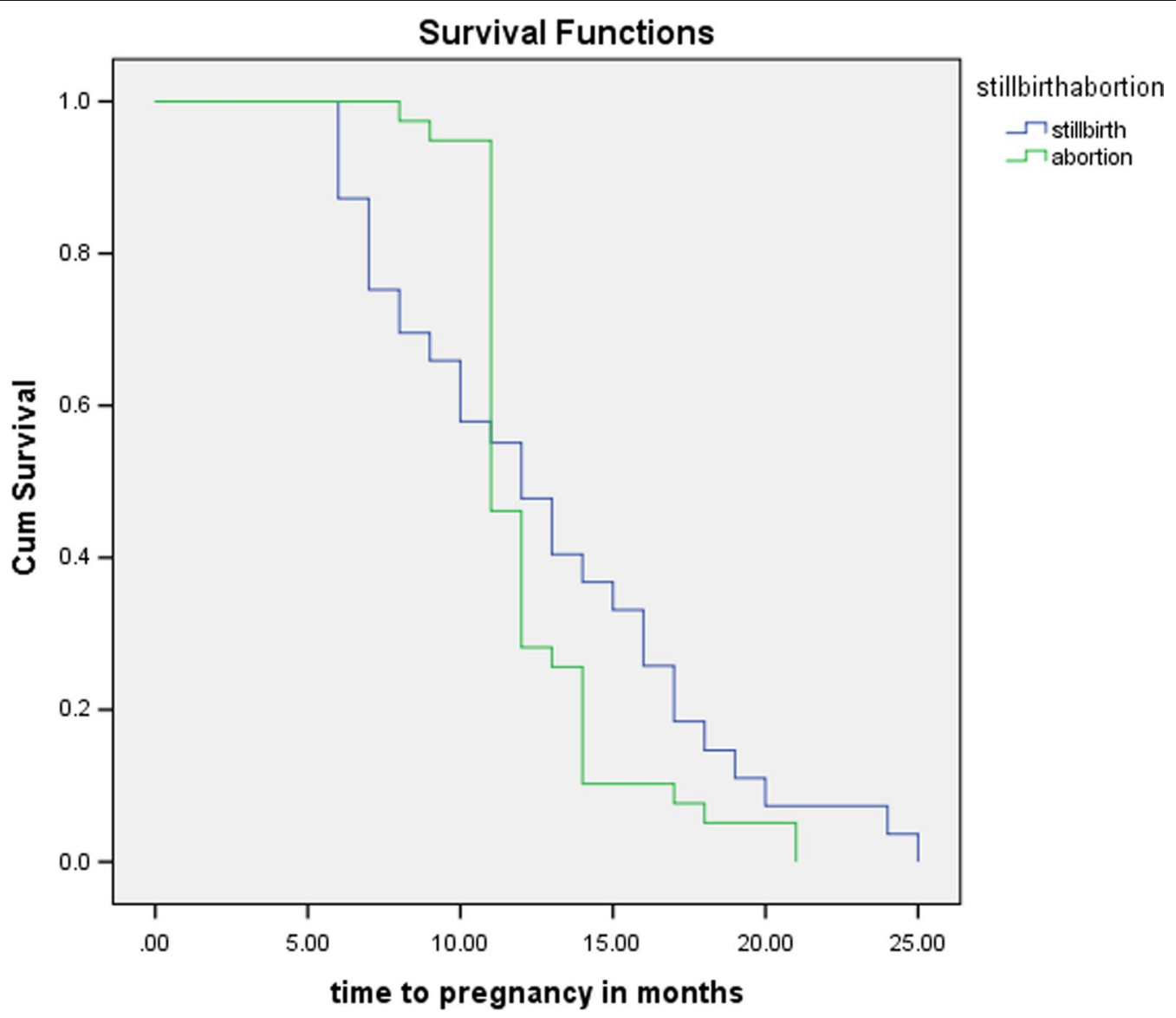

Fig. 1 Time to pregnancy after stillbirth and abortion 


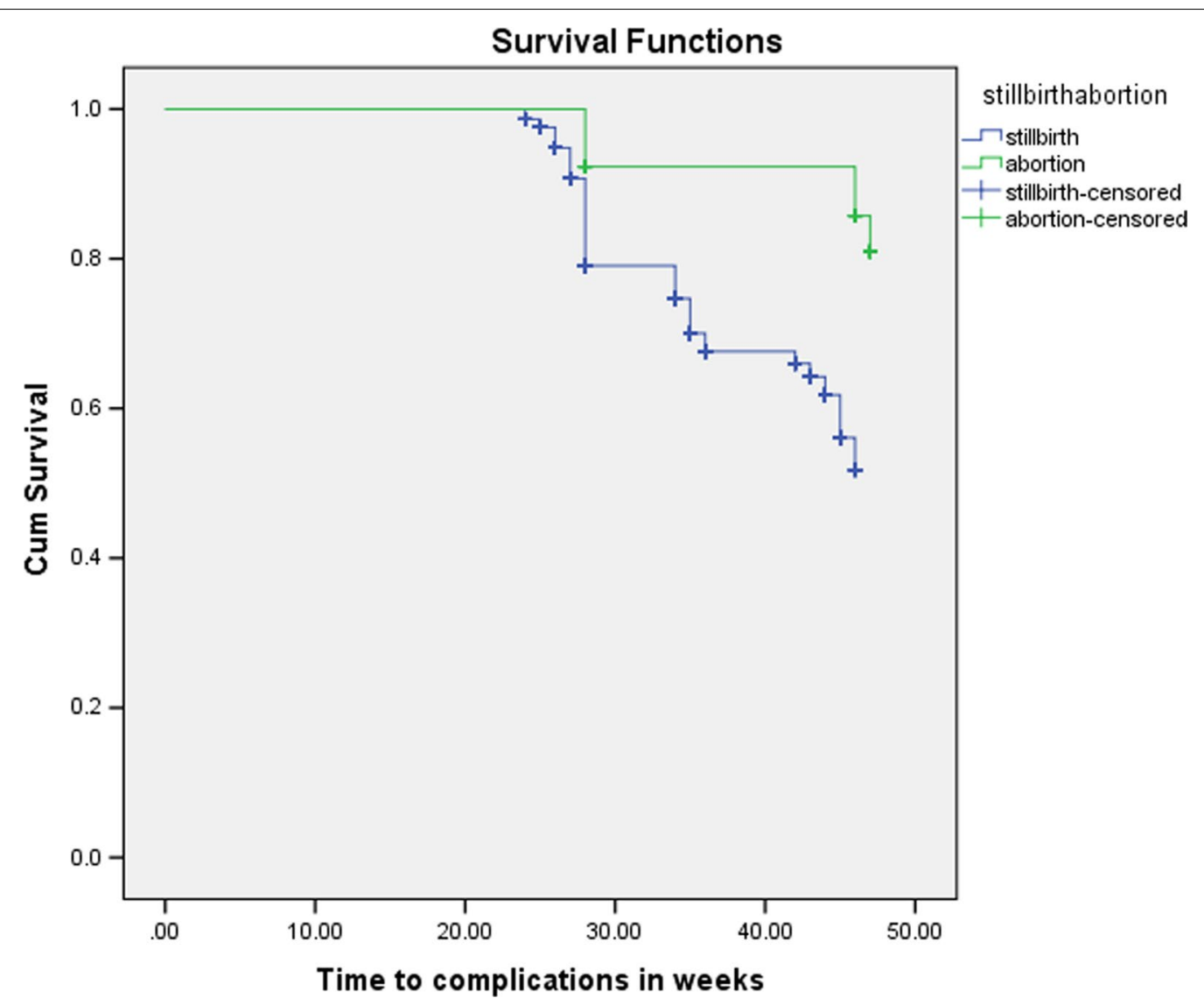

Fig. 2 Kaplan Meier survival curve for the pregnancy-related complications

DIABETES MELLITUS was observed 14.3\% of pregnant mothers with a past history of stillbirth and pregnancyinduced hypertension were observed on $9.2 \%$ of mothers with a past history of stillbirth (Table 4).

\section{Discussion}

Totally, 1042 stillbirths and 3026 abortion women were included. Most of the abortion women were single by marital status (91.2\%) but only $4.4 \%$ of stillbirth women were single. This finding agrees with researcher results from Nepal [21]. This occurs to the reason that pregnancy before marriage is usually unintended and unsupported ending with an abortion [22].

$58.1 \%$ of abortion women do not want to report the reason for abortion, but, post-traumatic stress disorder was present in $36.8 \%$ of the post-abortion women and $68.9 \%$ of the stillbirth women. This finding was in line with the 2017 finding [23]. The low prevalence of PTSD among post-abortion women indicates the high proportion of unintended pregnancy in the group [24].

The prevalence of hepatitis among abortion women was two folds higher than stillbirth women. Hepatitis B was present on $6 \%$ of the abortion women and $3.2 \%$ of

Table 4 Complications of stillbirth and abortion for the next pregnancy $(n=939)$

\begin{tabular}{|c|c|c|c|c|c|c|c|c|}
\hline & \multicolumn{2}{|l|}{ APH } & \multicolumn{2}{|l|}{ PPH } & \multicolumn{2}{|c|}{$\begin{array}{l}\text { Pregnancy induced diabetes } \\
\text { mellitus }\end{array}$} & \multicolumn{2}{|c|}{$\begin{array}{l}\text { Pregnancy induced } \\
\text { hypertension }\end{array}$} \\
\hline & Frequency & $\%$ & Frequency & $\%$ & Frequency & $\%$ & Frequency & $\%$ \\
\hline Stillbirth & 109 & 12.1 & 109 & 12.1 & 129 & 14.3 & 83 & 9.2 \\
\hline Abortion & 9 & 23.1 & 10 & 25.6 & 4 & 10.3 & 2 & 5.1 \\
\hline
\end{tabular}

$A P H$ ante-partum haemorrhage, $P P H$ post-partum hemorrhage 
the stillbirth women. This figure was higher as compared to the 2016 finding from Ethiopia [25]. This indicates that risky sexual behavior is increasing from time to time.

HIV was detected in $3 \%$ of abortion and $0.8 \%$ of stillbirth women. This finding was in line with the Uganda research outputs [26]. This is due to the reason that most abortion women were single with their marital status; they might have multiple sexual partners, which finally increase the risk of acquiring HIV.

Hepatitis $C$ was diagnosed in $4.7 \%$ of abortion and $0.3 \%$ of stillbirth women. This finding agrees with the research results from Egypt [27].

In the consecutive 3 years, $\mathrm{MCH}$ service was utilized by $75.7 \%$ of stillbirth women, but only $5.1 \%$ of abortion women utilized $\mathrm{MCH}$ service. The median time of pregnancy was 12 months for stillbirth and 11 months for abortion. This finding was in line with finding from Zambia [28]. This indicates that the tendency for repeated abortion was higher.

$\mathrm{MCH}$ service utilization was $29 \%$ higher in the presence of good knowledge regarding contraceptives [IRR 1.29, 95\% CI 1.18-1.42]. The Ghanaian research article also reported poor knowledge of contraceptives among abortion women [29]. This finding indicates that women should get access to family planning intervention to reduce the risk of unintended pregnancy.

$\mathrm{MCH}$ service utilization was 4.3 folds higher among women with tertiary education [IRR 4.29, 95\% CI $3.72-$ 4.96], 3.14 folds higher among women in secondary education. [IRR 3.14, 95\% CI 2.73-3.61], however, primary education was not helping women to use the $\mathrm{MCH}$ services. The previous finding from Ethiopia report the same results [30]. This indicates the government should extend its directions from primary education to secondary and above.

$\mathrm{MCH}$ service utilization was two folds higher among married women [IRR 2.08, 95\% CI: $1.84-2.34$ ]. This finding was in line with the Nigeria research article [13]. This is due to the reason that the probability of partner communication regarding $\mathrm{MCH}$ was high among married women than single women. Additionally, married women to have access to $\mathrm{MCH}$ services related to plan and helped pregnancy.

$\mathrm{MCH}$ service utilization was $49 \%$ lower in women living with high family-sized households [IRR $0.67,95 \% \mathrm{CI}$ 1.001-1.01]. This finding was in agreement with findings from Sub-Saharan African countries [31]. This indicates that people living in overcrowded areas will not have awareness about $\mathrm{MCH}$ services.

Antepartum hemorrhage (APH) was observed in 23.1\% of pregnant mothers with a past abortion women and post-partum hemorrhage ( $\mathrm{PPH}$ ) was observed in $25.6 \%$ pregnant mothers with a past history of abortion women.
Obstetric hemorrhage was a common complication of abortion for the next pregnancy. This is because the uterine procedures performed during abortion affects the integrity of the uterine wall predisposing risk factors like placenta previa and abruption [32, 33].

Stillbirth complicate the next pregnancy by predisposing the women for pregnancy induced diabetes mellitus and pregnancy induced hypertension; pregnancy induced diabetes mellitus was observed in $14.3 \%$ of pregnant mothers with a past history of stillbirth and pregnancyinduced hypertension was observed in $9.2 \%$ of mothers with a past history of stillbirth. This finding agrees with the previous finding from the same study area [34]. This is due to the endocrine effects of abortion and stillbirth $[35,36]$.

This research work did not assess the effects of stillbirth or abortion on the child health, and this is the limitation of this research.

\section{Conclusion}

Abortion women had poor knowledge of contraceptives, and unintended pregnancy was the predominant cause of abortion. Blood borne pathogens were common among abortion women. Primary education was not helpful to utilize $\mathrm{MCH}$ services. Obstetric hemorrhage was the common complications of abortion women for the next pregnancy. Pregnancy-induced diabetic Mellitus and pregnancy-induced hypertension were the most common complications of stillbirth for the next pregnancy.

\section{Recommendations}

The family planning program should extend its intervention to high school students. The post-abortion care should incorporate intervention for the blood borne pathogens. Emphasis should be given for women to accomplish at least secondary education. Pregnant women with the previous history of abortion should closely be followed to avert the risk of obstetric hemorrhage.

\section{Abbreviations}

APH: antepartum hemorrhage; B: beta-coefficient; $\mathrm{Cl}$ : confidence interval; ELIZA: enzyme-linked immune Sorbent assay; FANC: ante-natal care; HIV: human immunodeficiency virus; IRR: incident rate ration; $\mathrm{MCH}$ : maternal and child health; ML: milliliter; PPH: post-partum hemorrhage; PTSD: posttraumatic stress disorder scale; SD: standard deviation; SN: serial number; SOP: standard operating procedures.

\section{Acknowledgements}

Our heartfelt appreciation goes to the university of Bahir dar and Ethiopian ministry of health for financially sponsoring this research work. We would like to acknowledge the Amhara national, regional health officers for their unreserved efforts during the fieldwork. Our thanks also extended to Mecha district health offices for their positive support during the data collection 
stage. At last but not least, we would like to acknowledge all organizations and individuals that contributed to this work.

\section{Authors' contributions}

BEF conceived the experiment; BEF, AAN, EM and TEF performed the experiment, plan the data collection process, analyzed and interpreted the data. BEF, AAN, EM and TEF wrote the manuscript and approved the final draft for publication. All authors read and approved the final manuscript.

\section{Funding}

This research work was financially supported by federal democratic republic of Ethiopia ministry of health and Bahir Dar University. The funder has no role in design of the study and collection, analysis, and interpretation of data and in writing the manuscript.

\section{Availability of data and materials}

All data generated or analyzed during this study are included in this published article.

\section{Declarations}

\section{Ethics approval and consent to participate}

Ethical clearance was obtained from Bahir Dar University ethical review board with ethical Approval Number BDU 215/28 /2014, approval date November 2014. Written informed consent was obtained from each study participant. Study participants the right to withdraw from the study at any point was respected. The confidentiality of the data was kept at all stages. Study participants with Blood borne pathogens were linked to their respective services. All methods were carried out in accordance with relevant guidelines and regulations.

\section{Consent for publication}

Not applicable.

\section{Competing interests}

The authors declares that they have no competing interests.

\section{Author details}

'Department of Epidemiology and Biostatistics, University of Bahir Dar, Bahir Dar, Ethiopia. ${ }^{2}$ Department of Pediatrics, Wolkite University, Wolkite, Ethiopia. ${ }^{3}$ Department of Midwifery, University of Bahir Dar, Bahir Dar, Ethiopia. ${ }^{4}$ Department of Gynecology and Obstetrics, University of Bahir Dar, Bahir Dar, Ethiopia.

\section{Received: 11 March 2021 Accepted: 2 September 2021}

Published online: 25 September 2021

\section{References}

1. Blencowe H, Cousens S, Jassir FB, Say L, Chou D, Mathers C, Hogan D, Shiekh S, Qureshi ZU, You D, et al. National, regional, and worldwide estimates of stillbirth rates in 2015, with trends from 2000: a systematic analysis. Lancet Glob Health. 2016;4(2):e98-108.

2. Lawn JE, Lee AC, Kinney M, Sibley L, Carlo WA, Paul VK, Pattinson R, Darmstadt GL. Two million intrapartum-related stillbirths and neonatal deaths: where, why, and what can be done? Int J Gynaecol Obstet Off Organ Int Fed Gynaecol Obstet. 2009;107(Suppl 1):S5-18.

3. Stanton C, Lawn JE, Rahman H, Wilczynska-Ketende K, Hill K. Stillbirth rates: delivering estimates in 190 countries. The Lancet. 2006;367(9521):1487-94.

4. Fretts RC. Etiology and prevention of stillbirth. Am J Obstet Gynecol. 2005;193(6):1923-35.

5. Smith GCS, Fretts RC. Stillbirth. The Lancet. 2007;370(9600):1715-25.

6. Kumar A, Hessini L, Mitchell EMH. Conceptualising abortion stigma. Cult Health Sex. 2009;11(6):625-39.

7. Ganatra B, Gerdts C, Rossier C, Johnson BR, Tunçalp Ö, Assifi A, Sedgh G, Singh S, Bankole A, Popinchalk A, et al. Global, regional, and subregional classification of abortions by safety, 2010-14: estimates from a Bayesian hierarchical model. The Lancet. 2017;390(10110):2372-81.
8. Qiao J. Preconception care of patients with recurrent spontaneous abortion. Reprod Dev Med. 2019;3(2):63-8.

9. Upadhyay UD, Desai S, Zlidar V, Weitz TA, Grossman D, Anderson P, Taylor D. Incidence of emergency department visits and complications after abortion. Obstet Gynecol. 2015;125(1):175-83.

10. Calvert C, Owolabi OO, Yeung F, Pittrof R, Ganatra B, Tunçalp Ö, Adler AJ, Filippi $\mathrm{V}$. The magnitude and severity of abortion-related morbidity in settings with limited access to abortion services: a systematic review and meta-regression. BMJ Glob Health. 2018;3(3):e000692.

11. Tessema GA, Laurence CO, Melaku YA, Misganaw A, Woldie SA, Hiruye A, Amare AT, Lakew Y, Zeleke BM, Deribew A. Trends and causes of maternal mortality in Ethiopia during 1990-2013: findings from the Global Burden of Diseases study 2013. BMC Public Health. 2017;17(1):160.

12. Gebrehiwot $Y$, Liabsuetrakul T. Trends of abortion complications in a transition of abortion law revisions in Ethiopia. J Public Health. 2008;31(1):81-7.

13. Agunwa CC, Obi IE, Ndu AC, Omotowo IB, Idoko CA, Umeobieri AK, Aniwada EC. Determinants of patterns of maternal and child health service utilization in a rural community in south eastern Nigeria. BMC Health Serv Res. 2017;17(1):715.

14. Sarker AR, Sheikh N, Mahumud RA, Sultana M. Determinants of adolescent maternal healthcare utilization in Bangladesh. Public Health. 2018;157:94-103

15. Saad-Haddad G, DeJong J, Terreri N, Restrepo-Méndez MC, Perin J, Vaz L, Newby H, Amouzou A, Barros AJ, Bryce J. Patterns and determinants of antenatal care utilization: analysis of national survey data in seven countdown countries. J Glob Health. 2016;6(1):010404-010404.

16. Rutaremwa G, Wandera SO, Jhamba T, Akiror E, Kiconco A. Determinants of maternal health services utilization in Uganda. BMC Health Serv Res. 2015;15(1):271.

17. Sekoni O, Oladoyin V. Determinants of family planning uptake among men in Ibadan Nigeria. J Community Med Prim Health Care. 2016;28(1):38-44.

18. Sileo KM, Wanyenze RK, Lule H, Kiene SM. Determinants of family planning service uptake and use of contraceptives among postpartum women in rural Uganda. Int J Public Health. 2015;60(8):987-97.

19. Yaya S, Uthman OA, Amouzou A, Ekholuenetale M, Bishwajit G. Inequalities in maternal health care utilization in Benin: a population based crosssectional study. BMC Pregnancy Childbirth. 2018;18(1):194.

20. ADA. American Diabetes Association: standards of medical care in diabetes. Diabetes Care. 2005;28(Suppl. 1):S4-36.

21. Andersen KL, Khanal RC, Teixeira A, Neupane S, Sharma S, Acre VN, Gallo MF. Marital status and abortion among young women in Rupandehi, Nepal. BMC Women's Health. 2015;15(1):17.

22. Bearak J, Popinchalk A, Alkema L, Sedgh G. Global, regional, and subregional trends in unintended pregnancy and its outcomes from 1990 to 2014: estimates from a Bayesian hierarchical model. Lancet Glob Health. 2018;6(4):e380-9.

23. Chung MC, Reed J. Posttraumatic stress disorder following stillbirth: trauma characteristics, locus of control, posttraumatic cognitions. Psychiatr Q. 2017;88(2):307-21.

24. Wallin Lundell I, Sundström Poromaa I, Ekselius L, Georgsson S, Frans Ö, Helström L, Högberg U, Skoog Svanberg A. Neuroticism-related personality traits are associated with posttraumatic stress after abortion: findings from a Swedish multi-center cohort study. BMC Womens Health. 2017;17(1):96.

25. Mulu W, Zenebe Y, Abera B, Yimer M, Hailu T. Prevalence of human immunodeficiency virus and hepatitis $B$ virus infections in young women seeking abortion care in Ethiopia: a cross - sectional study. BMC Public Health. 2016;16(1):996.

26. Othieno C, Babigumira JB, Richardson B. Are women with complications of an incomplete abortion more likely to be HIV infected than women without complications? BMC Womens Health. 2015;15(1):95.

27. El-Kamary SS, Hashem M, Saleh DAA, Ehab M, Sharaf SA, El-Mougy F, Abdelsalam L, Jhaveri R, Aboulnasr A, El-Ghazaly H. Reliability of riskbased screening for hepatitis $C$ virus infection among pregnant women in Egypt. J Infect. 2015;70(5):512-9.

28. Stekelenburg J, Kyanamina S, Mukelabai M, Wolffers I, van Roosmalen J. Waiting too long: low use of maternal health services in Kalabo, Zambia. Trop Med Int Health. 2004;9(3):390-8. 
29. Biney AA. Exploring contraceptive knowledge and use among women experiencing induced abortion in the Greater Accra Region, Ghana. Afr J Reprod Health. 2011;15(1):37-46.

30. Tarekegn SM, Lieberman LS, Giedraitis V. Determinants of maternal health service utilization in Ethiopia: analysis of the 2011 Ethiopian Demographic and Health Survey. BMC Pregnancy Childbirth. 2014;14(1):161.

31. Owili PO, Muga MA, Chou Y-J, Hsu Y-HE, Huang N, Chien L-Y. Associations in the continuum of care for maternal, newborn and child health: a population-based study of 12 sub-Saharan Africa countries. BMC Public Health. 2016;16(1):414.

32. Dinis J, Doty M, Sibai BM. Risk factors for placental abruption between singleton and twin gestations [28L]. Obstet Gynecol. 2018;131:136S.

33. Gibbins KJ, Einerson BD, Varner MW, Silver RM. Placenta previa and maternal hemorrhagic morbidity. J Matern-Fetal Neonatal Med Off J Eur Assoc Perinatal Med Fed Asia Ocean Perinatal Soc Int Soc Perinatal Obstet. 2018;31(4):494-9.
34. Feleke BE. Determinants of gestational diabetes mellitus: a case-control study. J Matern-Fetal Neonatal Med Off J Eur Assoc Perinatal Med Fed Asia Ocean Perinatal Soc Int Soc Perinatal Obstet. 2018;31(19):2584-9.

35. Dimac-Stohl KA, Davies CS, Grebe NM, Stonehill AC, Greene LK, Mitchell J, Clutton-Brock T, Drea CM. Incidence and biomarkers of pregnancy, spontaneous abortion, and neonatal loss during an environmental stressor: implications for female reproductive suppression in the cooperatively breeding meerkat. Physiol Behav. 2018;193:90-100.

36. Roncati L, Piscioli F, Pusiol T. The endocrine disruptors among the environmental risk factors for stillbirth. Sci Total Environ. 2016;563-564:1086-7.

\section{Publisher's Note}

Springer Nature remains neutral with regard to jurisdictional claims in published maps and institutional affiliations.
Ready to submit your research? Choose BMC and benefit from:

- fast, convenient online submission

- thorough peer review by experienced researchers in your field

- rapid publication on acceptance

- support for research data, including large and complex data types

- gold Open Access which fosters wider collaboration and increased citations

- maximum visibility for your research: over $100 \mathrm{M}$ website views per year

At BMC, research is always in progress.

Learn more biomedcentral.com/submissions 